\title{
TINGKAT KEBISINGAN DI KAWASAN BANDAR UDARA TERHADAP LINGKUNGAN
}

\author{
F. Fariz \\ Jurusan Teknik Lingkungan, Fakultas Arsitektur Lanskap dan Teknologi Lingkungan, \\ Universitas Trisakti, Jakarta, Indonesia \\ Email korespondensi: fariz08212021@std.trisakti.ac.id
}

\begin{abstract}
ABSTRAK
Bandar udara ialah suatu tempat yang memiliki fasilitas untuk menampung kedatangan dan keberangkatan juga pergerakan pesawat terbang, penumpang dan barang yang diangkutnya. Kebutuhan masyarakat pada transportasi udara menimbulkan dampak kebisingan yang dihasilkan oleh pesawat saat landing dan take off terhadap kawasan sekitar bandar udara. Kebisingan adalah bunyi yang tidak diinginkan dari usaha atau kegiatan dalam tingkat dan waktu tertentu yang dapat menimbulkan gangguan kesehatan manusia dan kenyamanan lingkungan. Kebisingan pesawat dipengaruhi oleh faktor-faktor tertentu seperti jumlah penerbangan, jenis pesawat, dan jalur penerbangan, pada operasi pesawat terbang di bandara (mendarat dan lepas landas, taxiing, penyimpanan bahan bakar, pengujian mesin dan penggunaan unit daya tambahan). Kawasan kebisingan di bandar udara merupakan kawasan tertentu pada sekitar bandar udara yang terpengaruh dalam gelombang suara yang di hasilkan mesin pesawat terbang, terdapat tiga kategori kawasan kebisingan. Dampak yang di timbulkan dari aktivitas pesawat di bandar udara antara lain dapat manimbulka gangguan pendengaran, gangguan komunikasi, gangguan tidur, tingkat yang lebih tinggi dari stres yaitu kecemasan, depresi, morbiditas psikologis, gangguan hipertensi dan penyakit jantung coroner. pengendalian tingkat bising yang dapat dibagi ke dalam 3 aspek yaitu pengendalian pada sumber, rambatan dan penerima, Untuk meredam tingkat kebisingan di area sekitar bandar udara dapat di lakukan dengan cara menanam pohon yang rimbun dengan jarak tanam dan batas ketinggian yang sesuai pada lingkungan bandar udara yang dapat berfungsi sebagai zona penyangga.
\end{abstract}

Kata Kunci: Bandar udara, kebisingan pesawat terbang, lingkungan

\section{PENDAHULUAN}

Sistem transportasi mempunyai pengaruh besar pada perkembangan dan perubahan kegiatan sosial ekonomi suatu kota, sistem sosial ekonomi suatu kota juga akan mempengaruhi sistem transportasi yang ada. Sistem transportasi itu sendiri berfungsi untuk mengkoordinasikan proses pergerakan manusia dan barang dalam suatu kota dengan mengatur komponen-komponennya (Ferial,2016).

Bandar udara ialah suatu tempat yang memiliki fasilitas untuk menampung kedatangan dan keberangkatan juga pergerakan pesawat terbang, penumpang dan barang yang diangkutnya. Bandar udara juga merupakan gerbang untuk menghubungkan pusat-pusat perekonomian, wisata, dan pusat-pusat pemerintahan. Untuk menghubungkan tempat-tempat tersebut dipergunakan sarana transportasi antara lain pesawat terbang (Fortuna, 2016).

Trasportasi yang ideal bagi pergerakan manusia saat ini ialah pesawat terbang karena kecepatan yang di milikinya, sehingga banyak orang terutama pelaku bisnis dan wisatawan memilih alat transportasi ini untuk kegiatan bisnis dan wisatanya (Aldian, 2018)

Kebutuhan masyarakat pada transportasi udara menimbulkan dampak kebisingan yang dihasilkan oleh pesawat saat landing dan take off terhadap kawasan sekitar bandar udara. 
Pengaruh buruk dari kebisingan yang terus menerus dari aktivitas bandar udara tersebut sangat luas memberikan efek terhadap tingkah laku berupa fisiologi dan psikologis (Fachrul, dkk, 2016).

\section{TINJAUAN PUSTAKA}

\section{Kebisingan Pesawat Udara}

Kebisingan adalah sensasi pendengaran yang melewati telinga yang diakibatkan oleh penyimpangan tekanan udara (Fachrul, 2012). Pada umumnya ketergangguan (annoyance) terhadap suara-suara yang tidak diinginkan sangat berkaitan dengan kebisingan.

Kebisingan terjadi dimana-mana dan ketergangguan adalah reaksi yang paling umum terhadap bising (Michaud, 2005). Menurut Keputusan Menteri Lingkungan Hidup No. 48 tahun 1996 tentang baku tingkat kebisingan, kebisingan adalah bunyi yang tidak diinginkan dari usaha atau kegiatan dalam tingkat dan waktu tertentu yang dapat menimbulkan gangguan kesehatan manusia dan kenyamanan lingkungan Keputusan Menteri Lingkungan Hidup No. 48 tahun 1996.

Menurut Suma'mur (2009), berdasarkan sifat dan spektrum bunyi frekuensi bunyi, bising dibagi menjadi:

a. Kebisingan menetap berkelanjutan tanpa putus-putus dengan spektrum frekuensi yang lebar (steady state, wide bind noise), misalnya bising mesin, kipas angin, dapur pijar, dan lain-lain.

b. Kebisingan menetap berkelanjutan dengan spektrum frekuensi tipis (steady state dan narrow band noise), misalnya bising gergaji sirkuler, katup gas dan lain-lain.

c. Kebisingan terputus-putus (intermitten noise), misalnya bising lalu lintas suara kapal terbang di bandara.

d. Kebisingan impulsif (impact or impulsive noise), seperti bising pukulan palu, tembakan bedil atau meriam dan ledakan.

Kebisingan impulsif berulang, misalnya bising mesin tempa di perusahaan atau tempaan tiang pancang bangunan.Pada umumnya kebisingan pesawat dipengaruhi oleh faktor -faktor tertentu seperti jumlah penerbangan, jenis pesawat, dan jalur penerbangan, pada operasi pesawat terbang di bandara (mendarat dan lepas landas, taxiing, penyimpanan bahan bakar, pengujian mesin dan penggunaan unit daya tambahan) (Rodriguez, 2016). Suara pesawat udara adalah gangguan yang dihasilkan oleh pesawat atau komponennya, selama penerbangan, meluncur, mendarat dan lepas landas. Sari et al. (2014) mengklasifikasikan asal-usul kebisingan ini menjadi tiga sumber utama yaitu kebisingan aerodinamis, mesin pesawat dan sumber mekanis lainnya, sementara Arntzen dan Simons (2014) mengklasifikasikan kebisingan pesawat menjadi dua kategori: kebisingan mesin dan kebisingan airframe. Karena pangkal dari kebisingan pesawat terbang adalah pada saat dioperasikan atau dalam keadaan uji coba dan waktu perawatan, maka dapat dikatakan bahwa posisi pesawat terbang dan banyaknya pesawat terbang yang beroperasi pada saat yang bersamaan, akan sangat menentukan besarnya kebisingan yang dapat mempengaruhi lingkungan sekitarnya.

\section{Kawasan Kebisingan}

Kawasan kebisingan di bandar udara merupakan kawasan tertentu pada sekitar bandar udara yang terpengaruh dalam gelombang suara yang di hasilkan mesin pesawat terbang. Salah satu karakteristik kebisingan yang penting untuk kesehatan adalah intesitas. Intensitas adalah energi yang mengalir persatuan luas. Semakin jauh sumber suara, intensitas yang diterima akan semakin kecil, karena luas permukaan total yang dilalui 
semakin besar. Kebisingan berasal dari sumber suara, mesin pesawat terbang (Pratomo, 2010).

Berdasarkan persetujuan Direktorat Bandar Udara dengan dasar hukum Keputusan Menteri Perhubungan nomor KM 48 Tahun 2002 Tentang Penyelenggaraan Bandar Udara, menetapkan bahwa:

a. Kawasan kebisingan di bandar udara diukur dan ditentukan dengan bertitik tolak pada rencana induk bandar udara;

b. Tingkat kebisingan ditentukan berdasarkan Weighted Equivalent Continuous Perceived Noise Level (WECPNL);

c. Tingkat kebisingan terdiri dari :

Kawasan kebisingan tingkat I dengan nilai WECPNL lebih besar atau sarna dengan 70 dan lebih keeil $75(70=$ WECPN1 $<75)$, yaitu tanah dan ruang udara yang dapat dimantaatkan untuk berbagai jenis kegiatan dan atau bangunan kecuali untuk jenis bangunan sekolah dan rumah sakit;

Kawasan kebisingan tingkat II dengan nilai WECPNL lebih besar atau sama dengan 75 dan lebih keeil $80(75=$ WECPNl $<80)$, yaitu tanah dan ruang udara yang dapat dimantaatkan untuk berbagai jenis kegiatan dan atau bangunan keeuafi untuk jenis kegiatan dan/atau bangunan sekolah, rumah sakit dan rumah tinggal; dan

Kawasan kebisingan tingkat III dengan nilai WECPNL lebih besar atau sama dengan 80 $(80=$ WECPN1), yaitu tanah dan ruang udara yang dapat dimanfaatkan untuk membangun tasilitas bandar udara yang dilengkapi insulasi suara dan dapat dimanfaatkan sebagai jalur hijau atau sarana pengendalian Iingkungan dan pertanian yang tidak mengundang burung

\section{DAMPAK KEBISINGAN}

Kebisingan, digambarkan sebagai suara yang tidak diinginkan (Schmidt, 2005), diketahui memiliki beberapa efek buruk pada manusia, seperti gangguan pendengaran, gangguan komunikasi, gangguan tidur, tingkat yang lebih tinggi yaitu dapat menimbulkan stres kecemasan, depresi, morbiditas psikologis, gangguan hipertensi dan penyakit jantung koroner (Janssen et al., 2014). Kebisingan dengan kekuatan $80 \mathrm{~dB}$ dengan paparan waktu panjang dapat menyebabkan kegelisahan, menurunkan vitalitas tubuh, menimbulkan rasa jenuh, sakit lambung dan mengurangi kepekaan kulit. Kebisingan juga menjadi salah satu penyebab terjadinya gangguan pembicaraan yang dapat menyebabkan salah pengertian dari penerimaan pembicaraan. Agar komunikasi berjalan lancar maka kebisingan yang boleh terjadi pada ruang bekerja berkisar antara $65-75 \mathrm{~dB}(\mathrm{~A})$.

Kebisingan yang mencapai $85 \mathrm{~dB}$ dapat menurunkan kondisi kesehatan manusia secara serius. Suasana bising yang terdapat dalam ruang kerja dapat merusak efisiensi kerja karena dapat mengganggu konsentrasi dalam berpikir, sehingga menurunkan jumlah efektifitas kerja. Pengurangan kebisingan sebesar $20 \mathrm{~dB}$ di tempat bekerja mampu meningkatkan kapasitas kerja sampai $20 \%$ serta dapat menurunkan kesalahan ucap hingga $29 \%$.

\section{PENGENDALIAN KEBISINGAN}

Menurut Mochamad Chaeran, (2008) Secara umum upaya pengendalian kebisingan dilakukan melalui pengurangan dan pengendalian tingkat bising yang dapat dibagi ke dalam 3 aspek yaitu:

1. Pengendalian pada sumber

Pengendalian kebisingan pada sumber meliputi: 
a. Perlindungan pada peralatan, struktur, dan pekerja dari dampak bising.

b. Pembatasan tingkat bising yang boleh dipancarkan sumber

2. Pengendalian pada rambatan

Pengendalian pada media rambatan dilakukan diantara sumber dan penerima kebisingan. Prinsip dasar pengendaliannya adalah melemahkan intensitas kebisingan yang merambat dari sumber kepenerima dengan cara membuat hambatan-hambatan. Dua cara pengendaliannya yaitu outdoor noise control dan indoor noise control.

3. Pengendalian kebisingan pada penerima

Pengendalian kebisingan pada penerima dilakukan untuk mereduksi tingkat kebisingan yang diterima setiap hari. Pengendalian ini terutama ditujukan pada penerima yang setiap harinya menerima kebisingan, seperti operator pesawat terbang dan orang lain yang menerima kebisingan. Pada manusia kerusakan akibat kebisingan diterima oleh pendengaran (telinga bagian dalam) sehingga metode pengendaliannya memanfaatkan alat bantu yang bisa mereduksi tingkat kebisingan yang masuk ke telinga. Salah satu cara untuk meminimalisir kebisingan di bandar udara yaitu menanam pohon yang rimbun. Penanaman pohon yang rimbun dengan jarak tanam dan batas ketinggian yang sesuai pada lingkungan bandar udara dapat berfungsi sebagai zona penyangga (Martelens Ch. Liu, 2011).

\section{PENUTUP}

Dampak yang di timbulkan dari aktivitas pesawat di bandar udara antara lain dapat manimbulka gangguan pendengaran, gangguan komunikasi, gangguan tidur, tingkat yang lebih tinggi dari stres yaitu kecemasan, depresi, morbiditas psikologis, gangguan hipertensi dan penyakit jantung coroner. Untuk meredam tingkat kebisingan di area sekitar bandar udara dapat di lakukan dengan cara menanam pohon yang rimbun dengan jarak tanam dan batas ketinggian yang sesuai pada lingkungan bandar udara yang dapat berfungsi sebagai zona penyangga.

\section{DAFTAR PUSTAKA}

Aldian, F. 2018. Kajian Tingkat Kebisingan Pesawat Udara di Bandar Udara Sultan Thaha, Jambi. Fakultas Arsitektur Lanskap dan Teknologi Lingkungan. Universitas Trisakti.

Artnez, M., Simons, D.G., 2014. Modeling and Syntesis of Aircraft Flyover Noise.

Babba J (2007). Hubungan Intensitas Kebisingan di Tempat Kerja dengan Peningkatan Tekanan Darah. Tesis. Semarang. Universitas Diponegoro.

Bachtiar, V.S., R. Afrinita dan A. Zamzamy. 2018. Evaluasi Tingkat Kebisingan Kawasan Selatan Universitas Negeri Padang. Jurnal Dampak. 15 (1):

7-15. https://doi.org/10.25077/dampak.15.1.7-15.2018

Berglund, B., Lindvall, T., dan Schwela, D. H. 1999. Guidelines For Community Noise. World Health Organization (WHO), Geneva. London, UK.

Diaz, A.R. 2016. Transpotrtation Research Part D Escuela Politécnica de Ingeniería de Gijón, Universidad de Oviedo, Spain.

Direktorat Jenderal Perhubungan Udara, 2007 dalam Asidah, Evita 2007.

Fachrul, M. F., H. Yulinawati, dan Ernawati. 2016. Analisis Pengaruh Tingkat Kebisingan Lalulintas Terhadap Lingkungan Kampus A - Universitas Trisakti A Grogol, Jakarta Barat dan Masyarakat di Sekitarnya. Indonesian Jurnal of Urban and Environmental Technology. Vol. 6, No. 2.

DOI: http://dx.doi.org/10.25105/urbanenvirotech.v6i2.702 
Janssen, S.A., Centen, M.R., Vos, H., Van Kamp, I., 2014. The Effect of the Number of Aircraft Noise Events on Sleep Quality. Appl. Acoust. 84 (1), 9-16.

Suroto, W. 2010. Dampak Kebisingan Lalu Lintas Terhadap Pemukiman Kota (Kasus Kota Surakarta). Jurnal of Rulan and Development. Volume 1, No. 1 Februari 2010.

Fortuna, L. 2016. Kajian Tingkat Kebisingan Di Terminal 3 Bandar Udara Internasional Soekarno Hatta, Tangerang, Provinsi Banten. Jakarta: Universitas Trisakti

Pratomo, Suko.2010.Sumber Daya Alam dan Pencemaran/Polusi

1996, Keputusan Menteri Negara Lingkungan Hidup (KepMenLH) No. 48 Tahun 1996, Tentang : Baku Tingkat Kebisingan, Kementrian Lingkungan Hidup Republik Indonesia, Jakarta

2002, Keputusan Menteri Perhubungan No. KM 48 Tahun 2002 tentang Penyelenggaraan Bandar Udara, Kementrian Perhubungan Republik Indonesia,Jakarta 